Acta vet. scand. $1984,25,128-138$.

From the Tronheim Public Food Control Laboratory, Regional Veterinary Office, Tronheim, Norwegian Defence Research Establishment, Kjeller, and Reindeer Control, Røros, Norway.

\title{
PHYSIOLOGICAL RESPONSES AND EFFECTS ON MEAT QUALITY IN REINDEER (RANGIFER TARANDUS) TRANSPORTED ON LORRIES
}

\author{
By \\ I. Hanssen, A. Kyrkjebø, P. K. Opstad and R. Prøsch
}

HANSSEN, I., A. KYRKJEB $\emptyset$, P. K. OPSTAD and R. PंRøSCH: Physiological responses and effects on meat quality in reindeer (Rangifer tarandus) transported on lorries. Acta vet. scand. 1984, 25, 128-138. - Reindeer transported on lorries to the slaughterhouse showed strongly elevated plasma noradrenaline, adrenaline and cortisol values. Plasma creatine kinase and aspartate aminotransferase activity measurements gave no evidence of muscle damage, but by cooking ammonia-like and another taint were observed in the meat from about $25 \%$ of the transported reindeer. A control group consisting of reindeer slaughtered from the gathering corral also showed a high prevalence of these meat taints. Plasma and meat urea values were elevated in the transported reindeer, but there was no correlation between the meat urea values and the intensities of ammonia-like taint. The charecter of the other observed taint was not defined.

reindeer; transport; catecholamines; meat taints.

Reindeer (Rangifer tarandus) have been herded by the Lapps for hundreds of years, and methods for management have developed gradually. During the last $10-20$ years these methods have changed enormously. Snow-scooters and helicopters are now commonly used for gathering, and ships and lorries for transport.

To improve the meat hygienic standard slaughtering in officially sanctioned slaughterhouses has been stimulated, and field slaughtering has been correspondingly reduced. This implicates that the reindeer have to be locked up and transported on lorries before slaughtering. Andersen (1978) found that reindeer could be transported without detrimental effects on the meat quality 
if the lorry plane was devided in small compartments and calves and adults were separated.

Hyvärinen et al. (1976) and Rehbinder \& Edqvist (1981) found, however, that handling the reindeer affected serveral blood parameters. In both studies a rise in plasma urea values was found, which they suggested might be of significance for explaining the urine-like tasie of meat from reindeer that have been transported over long distances or have spent a long time in the corral.

Rehbinder et al. (1982) found abomasal hemorrhages, muscular and myocardial degenerations and marked changes in blood parameters in herded, handled and transported reindeer. They concluded that transportation to slaughterhouse and keeping reindeer in corrals, pens or crates whilst awaiting slaughter will result in lowered meat quality.

This study was an attempt to measure the fear reactions and meat quality of transported reindeer. As changes in the rumen contents have been related to foul taint of reindeer meat, we have made some examinations of rumen contents as well.

\section{Handling of animals}

\section{MATERIAL AND METHODS}

Six different groups of reindeer were studied during the period 4 th of November to 10th of December (Table 1).

Table 1. Handling of reindeer.

\begin{tabular}{|c|c|c|c|c|c|c|c|}
\hline \multirow{2}{*}{$\begin{array}{l}\text { Origin } \\
\text { of herd }\end{array}$} & \multirow{2}{*}{\multicolumn{2}{|c|}{ Group }} & \multirow{2}{*}{$\begin{array}{l}\text { Hours in the } \\
\text { corral before } \\
\text { transport }\end{array}$} & \multicolumn{2}{|c|}{ Transport } & \multicolumn{2}{|c|}{ Hours from end of Slaughter- } \\
\hline & & & & Km & Hours & $\begin{array}{l}\text { the transport to } \\
\text { slaughtering }\end{array}$ & house \\
\hline \multirow{2}{*}{\multicolumn{8}{|c|}{$\begin{array}{l}\text { Trollheimen } \\
\text { S-Trøndelag, }\end{array}$}} \\
\hline & & & & & & & \\
\hline Møre and & Control & 2 & 20 & & - B & - & 一 \\
\hline \multicolumn{8}{|l|}{ Romsdal } \\
\hline County & Test & 1 & 36 & 230 & 4 & 8 & Brekken \\
\hline Femundmarka & Test & 2 & 3 & 180 & 3 & 2 & Brekken \\
\hline \multicolumn{8}{|l|}{ Hedemark } \\
\hline County & Test & 3 & 3 & 180 & 3 & 12 & Brekken \\
\hline Røyrvik & Test & 4 & 48 & 120 & 2 & 0 & Namsos \\
\hline \multicolumn{8}{|l|}{ N-Trøndelag } \\
\hline County & & & & & & & \\
\hline
\end{tabular}

A Free-ranging, shot with a rifle.

B Taken out by lasso and stunned beside the corral. 
Co ntrol group 1: 3 reindeer (11/2 years old, 2 females and 1 male) supposed to be undisturbed before being shot in the head with a rifle.

C o n t r o l g r o u p 2: 7 reindeer (11/2 years old, both sexes) from a herd driven by snow-scooter into a corral before they were taken out by lasso and stunned with a bolt pistol.

Test group 1: 16 reindeer (calves and 1/1/2 years old, both sexes, and 1 male $2 \frac{1}{2}$ year), were driven by snow-scooters into a corral before they were loaded on a lorry plane that was divided into 6 compartments, each $110 \times 250 \mathrm{~cm}$. Calves and adults were separated and each compartment contained either 8 calves or 6 adults. After unloading, the reindeer were let into a corral from which they were gently lead in groups of $2-4$ deer via a smaller corral into a room where they were stunned with a bolt pistol.

Test g r o u p: 22 reindeer (calves and 11/2 years old, both sexes) driven by snow-scooter into a corral before they were loaded on a lorry. The lorry plane was of the same type as described for Test group 1, but each compartment was loaded with 2 more reindeer than in the transport of Test group 1. The reindeer were unloaded into the same corral system as Test group 1.

Tes t g r o u p 3: 7 reindeer (calves and 11/2 years old, both sexes) from the same herd as Test group 2 and transported on the same lorry type.

Test group 4: 17 reindeer (calves and 11/2 years old, both sexes) gathered and driven by snow-scooters into a corral from which they were loaded on a lorry plane, that was divided into 3 compartments, each $2.50 \times 2.50 \mathrm{~m}$. Calves and adults were loaded in the same compartment, each containing 12-13 deer. The reindeer were unloaded into a stable and locked up in a sheepcot, from where one after another were taken into an adjacent room and stunned.

The reindeer were offered lichen and hay during their stay in the corrals. The ambient temperatures during the transports ranged between 0 and $\div 10^{\circ} \mathrm{C}$.

\section{Body temperatures}

Immediately after the reindeer had been stunned and bled, a temperature probe was inserted deeply into the medial leg muscles. Temperature was read on a Kane-May 1012 instrument. 


\section{Plasma investigations}

Slaughter blood was taken on heparinized tubes. The blood was sentrifuged, and the plasma specimens were frozen at $\div 20^{\circ} \mathrm{C}$ till they were analyzed.

H o r m o n e s. Dopamin, adrenaline and noradrenaline were determined by a radioenzymatic assay based on 3-0-methylation of the amines by catechol-0-methyl-transferase and S-adenolsylL-(methyl- $\left.{ }^{3} \mathbf{H}\right)$-methionine. The methylated amines were extracted by ether and sodiumtetraphenylborate, were oxidized by $\mathrm{NaIO}_{4}$ and extracted in toluol (Da Prada \& Zürcher 1976).

E $n z$ y m e s. The activities of ASAT (aspartate aminotransferase) and CK (creatine kinase) were measured by reaction rate analysis at $37^{\circ} \mathrm{C}$ on an automated Hitachi 705 spectrophotometer, using kits from Boehringer Mannheim.

M e $t$ a b o l it e s. Glukose was analyzed using the hexokinase method (Boehringer Mannheim). Urea was analysed on a computer controlled multichannel biochemical analyser (Technicon SMA II) after a modified method of the carbamidodiacetyl reaction (Marsh et al. 1965).

\section{Meat investigations}

p $\mathrm{H}-\mathrm{m}$ e a s u r e m e n t s. A pH probe was inserted into $\mathrm{M}$. longissimus dorsi $18-24 \mathrm{~h}$ post morten and values were read on a Kane-May 7001 instrument.

U r e a. Duplicates of $2.5 \mathrm{~g}$ meat from the dorsal neck were homogenized in $50 \mathrm{ml}$ phosphate buffer in a warring blender. The homogenized meat was filtered and the filtrate was diluted up to $100 \mathrm{ml}$. The filtrate was incubated with urease and released ammonia was allowed to react with alkaline hypoclorite and phenol, to form indophenol (Chaney \& Marback 1962). The indophenol was measured on a Hitachi 101 spectrophotometer. A blind specimen was measured to correct for ammonia.

\section{Sensory analysis}

Meat taken from the dorsal neck region were cooked for about $1 \frac{1}{2} \mathrm{~h}$. Two well trained persons were asked to grade presence of ammonia-like, gut content-like, other abnormal and game smell and taste into following cathegories: not present $(0)$, barely detectable (1), weak (2), strong (3). 
Rumen contents

U rea/a m m o $\mathrm{n}$ a a n a lysis. Duplicates of $5 \mathrm{~g}$ rumen contents were mixed with $50 \mathrm{ml}$ phosphate buffer and filtered. The filtrate was diluted up to $100 \mathrm{ml}$ and treated as described for the meat extract.

D r y m a t e r. 5 g rumen contents were dried over night at $105^{\circ} \mathrm{C}$ and subsequently weighed.

\section{Statistical methods}

Values of measured parameters were tested by one way analysis of variance (ANOVA). Difference between two groups was tested by t-test. Frequencies of meat ammonia-like and other abnormal taint were tested by $\chi^{2}$-test. Significance was set at the $1 \%$ level for all tests.

\section{RESULTS}

The results are presented in Tables 2 and 3 with the exception of subcutanous hemorrhages.

\section{Subcutanous hemorrhages}

Test group 2 showed high prevalence $(8 / 22)$ of subcutanous hemorrhages. The hemorrhages varied from small to extensive, and 2 deer were condemned by the meat control. Otherwise subcutaneous hemorrhages were noticed in 1 animal from Test group 1.

\section{Plasma investigations}

H o r m o n e s. The catecholamines showed great individual variations, but were significantly higher in transported reindeer compared to those slaughtered from the corral. One of the freeranging showed high adrenaline and noradrenaline concentrations. The dopamin concentrations were consistently low, ranging from undetectable to $4.2 \mathrm{nmol} / \mathrm{l}$.

The cortisol concentrations also varied a great deal within the groups, but were significantly higher in the test deer compared to the controls.

Enzy mes. The ASAT activities were significantly higher in transported reindeer compared to the controls.

The CK activities varied much within all groups except among the free-ranging. The controls showed significantly lower act- 
T a ble 2. Plasma hormones, enzymes and metabolites in reindeer. Significant variations and differences are marked with an asterisk.

\begin{tabular}{|c|c|c|c|c|c|c|c|}
\hline Groups & $\begin{array}{l}\text { Nor- } \\
\text { adrenalin } \\
\text { nmol/1 } \\
\overline{\mathrm{x}}, \text { range }\end{array}$ & $\begin{array}{l}\text { Adrenaline } \\
\text { nmol/1 } \\
\overline{\mathrm{x}}, \text { range }\end{array}$ & $\begin{array}{l}\text { Cortisol } \\
\text { nmol/1 } \\
\overline{\mathrm{x}}, \text { range }\end{array}$ & $\begin{array}{l}\text { CK } \\
\mathrm{U} / 1 \\
\overline{\mathrm{X}}, \text { range }\end{array}$ & $\begin{array}{l}\text { ASAT } \\
\mathbf{U} / \mathbf{l} \\
\overline{\mathbf{x}} \pm \mathbf{s}\end{array}$ & $\begin{array}{l}\text { Glucose } \\
\text { nmol/1 } \\
\overline{\mathbf{x}} \pm \mathrm{s}\end{array}$ & $\begin{array}{l}\text { Urea } \\
\text { nmol/l } \\
\overline{\mathbf{x}} \pm \mathrm{s}\end{array}$ \\
\hline $\begin{array}{l}\text { Free- } \\
\text { ranging } \\
\text { (Control 1) }\end{array}$ & $\begin{array}{l}33.6 \\
3.6-87.6\end{array}$ & $\begin{array}{l}86.3 \\
18.3-213.0\end{array}$ & $\begin{array}{l}30 \\
16-37\end{array}$ & $\begin{array}{l}156 \\
150-163\end{array}$ & $72 \pm 13$ & $6.1 \pm 1.6$ & $4.1 \pm 2.8$ \\
\hline $\begin{array}{l}\text { Slaughtered } \\
\text { from the } \\
\text { corral } \\
\text { (Control 2) }\end{array}$ & $\begin{array}{l}8.0 \\
3.4-17.8\end{array}$ & $\begin{array}{l}13.0 \\
2.8-31.8\end{array}$ & $\begin{array}{l}109 \\
80-212\end{array}$ & $\begin{array}{l}393 \\
220 \_4505\end{array}$ & $87 \pm 18$ & $7.9 \pm 2.0$ & $14.1 \pm 2.2$ \\
\hline $\begin{array}{l}\text { Transported } \\
230 \mathrm{~km} \text { and } \\
\text { held } 6-7 \mathrm{~h} \\
\text { before sla- } \\
\text { ugthering } \\
\text { (Test } 1 \text { ) }\end{array}$ & $\begin{array}{cc}96.4 & \\
15.4-283.2\end{array}$ & $\begin{array}{l}120 \\
40-365\end{array}$ & $\begin{array}{l}273 \\
82 \_889\end{array}$ & $\begin{array}{l}1007 \\
270 \_4435\end{array}$ & $157 \pm 62$ & $10.9 \pm 2.4$ & $24.1 \pm 2.8$ \\
\hline $\begin{array}{l}\text { Transported } \\
180 \mathrm{~km} \text { and } \\
\text { slaughtered } \\
\text { immediately } \\
\text { afterwards } \\
\text { (Test 2) }\end{array}$ & $\begin{array}{lr}66.2 & \\
27.9-163.2\end{array}$ & $\begin{array}{l}113.0 \\
7.6-269.0\end{array}$ & $\begin{array}{l}217 \\
65-760\end{array}$ & $\begin{array}{l}2311 \\
121-7870\end{array}$ & $146 \pm 60$ & $14.2 \pm 4.5$ & $6.9 \pm 2.0$ \\
\hline $\begin{array}{l}\text { Transported } \\
180 \mathrm{~km} \text { and } \\
\text { held } 12 \mathrm{~h} \\
\text { before } \\
\text { slaughtering } \\
\text { (Test } 3 \text { ) }\end{array}$ & $\begin{array}{l}151.8 \\
20.9 — 263.5\end{array}$ & $\begin{array}{l}184.1 \\
60.3-422.6\end{array}$ & $\begin{array}{l}171 \\
77-304\end{array}$ & $\begin{array}{l}662 \\
124-1350\end{array}$ & $121 \pm 48$ & $10.9 \pm 2.9$ & $24.1 \pm 2.8$ \\
\hline $\begin{array}{l}\text { Transported } \\
120 \mathrm{~km} \text { and } \\
\text { slaughtered } \\
\text { immediately } \\
\text { afterwards } \\
\text { (Test 4) }\end{array}$ & $\begin{array}{l}49.5 \\
13.5-88.3\end{array}$ & $\begin{array}{l}97.3 \\
2.0-171\end{array}$ & $\begin{array}{c}817 \\
164-1732\end{array}$ & $\begin{array}{l}1760 \\
560-3280\end{array}$ & $162 \pm 36$ & $8.8 \pm 2.0$ & $24.8 \pm 7.6$ \\
\hline ANOVA & * & * & * & * & * & * & * \\
\hline t-test & $\begin{array}{l}\text { Control } 1 \\
\text { versus } \\
\text { Control } 2\end{array}$ & $\begin{array}{l}\text { Control } 1 \\
\text { versus } \\
\text { Control } 2\end{array}$ & $\begin{array}{l}\text { Controls } \\
\text { versus } \\
\text { Tests }\end{array}$ & $\begin{array}{c}\text { Test } 1 \\
\text { and } 3 \\
\text { versus } \\
\text { Test } 2 \\
\text { and } 4 \\
\star\end{array}$ & $\begin{array}{l}\text { Controls } \\
\text { versus } \\
\text { Tests }\end{array}$ & $\begin{array}{l}\text { Control } 1 \\
\text { versus } \\
\text { Control } 2\end{array}$ & $\begin{array}{l}\text { Control } 1 \\
\text { versus } \\
\text { Test } 2\end{array}$ \\
\hline
\end{tabular}


T a b l e 3. Body temperatures and meat and rumen contents analyses in reindeer. Significant variations are marked with an asterisk,

\begin{tabular}{|c|c|c|c|c|c|c|c|}
\hline \multirow[b]{2}{*}{ Groups } & \multirow[b]{2}{*}{$\begin{array}{l}\text { Body } \\
\text { temp. } \\
{ }^{\circ} \mathrm{C} \\
\overline{\mathrm{x}} \pm \mathrm{S}\end{array}$} & \multicolumn{4}{|c|}{ Meat } & \multicolumn{2}{|c|}{ Rumen contents } \\
\hline & & $\begin{array}{c}\text { urea } \\
\mathrm{nmol} / \mathrm{kg} \\
\overline{\mathbf{x}} \pm \mathrm{s}\end{array}$ & $\begin{array}{c}\text { ph } \\
\text { 18-24th } \\
\text { p.m. } \\
\bar{x} \pm s\end{array}$ & $\begin{array}{c}\text { Ammonia } \\
\text { like } \\
\text { taint } \\
\text { (preva- } \\
\text { lence) }\end{array}$ & $\begin{array}{c}\text { Other } \\
\text { abnormal } \\
\text { taints } \\
\text { (preva- } \\
\text { lence) }\end{array}$ & $\begin{array}{c}\text { Ammonia } \\
\mathbf{n m o l} / \mathbf{k g} \\
\overline{\mathrm{x}} \pm \mathrm{s}\end{array}$ & $\begin{array}{c}\text { Dry } \\
\text { matter } \\
\% \\
\bar{x} \pm s\end{array}$ \\
\hline $\begin{array}{l}\text { Free- } \\
\text { ranging } \\
\text { (Control 1) }\end{array}$ & $38.0 \pm 0.4$ & $4.0 \pm 1.2$ & $5.4 \pm 0.1$ & $0 / 3$ & $0 / 3$ & $9.6 \pm 2.7$ & $20.4 \pm 0.8$ \\
\hline $\begin{array}{l}\text { Slaughtered } \\
\text { from the } \\
\text { corral } \\
\text { (Control 2) }\end{array}$ & $39.5 \pm 0.5$ & $8.2 \pm 5.2$ & - & $2 / 7$ & $4 / 7$ & $19.7 \pm 4.3$ & $15.8 \pm 2.6$ \\
\hline $\begin{array}{l}\text { Transported } \\
230 \mathrm{~km} \text { and } \\
\text { held } 6-7 \mathrm{~h} \\
\text { before } \\
\text { slaughtering } \\
\text { (Test 1) }\end{array}$ & $38.2 \pm 0.4$ & $10.5 \pm 2.7$ & $6.3 \pm 0.5$ & $6 / 15$ & $5 / 15$ & $25.7 \pm 8.0$ & $15.3 \pm 2.7$ \\
\hline $\begin{array}{l}\text { Transported } \\
180 \mathrm{~km} \text { and } \\
\text { slaughtered } \\
\text { immediately } \\
\text { afterwards } \\
\text { (Test 2) }\end{array}$ & $38.7 \pm 0.5$ & $4.7 \pm 2.3$ & $6.0 \pm 0.2$ & $4 / 20$ & $5 / 20$ & - & $17.5 \pm 2.3$ \\
\hline $\begin{array}{l}\text { Transported } \\
180 \mathrm{~km} \text { and } \\
\text { held } 12 \mathrm{~h} \\
\text { before } \\
\text { slaughtering } \\
\text { (Test 3) }\end{array}$ & $38.4 \pm 0.7$ & $12.7 \pm 4.2$ & $5.8 \pm 0.3$ & $1 / 6$ & $0 / 6$ & - & $14.2 \pm 1.5$ \\
\hline $\begin{array}{l}\text { Transported } \\
120 \mathrm{~km} \text { and } \\
\text { slaughtered } \\
\text { immediately } \\
\text { afterwards } \\
\text { (Test 4) }\end{array}$ & $39.5 \pm 0.8$ & $15.8 \pm 3.0$ & $6.3 \pm 0.3$ & $3 / 13$ & $3 / 13$ & - & - \\
\hline $\begin{array}{l}\text { ANOVA } \\
\chi^{2} \text {-test }\end{array}$ & * & * & * & n.s. & n.s. & * & * \\
\hline
\end{tabular}


ivities than the test groups. It was also evident the tests held 6$12 \mathrm{~h}$ after transport before slaughtering had lower $\mathrm{CK}$ values than those slaughtered directly after the transport.

Metabolites. Control group 1 and Test group 2 had significantly lower urea levels compared to the other test groups, while Control group 2 was intermediate. Elevated plasma glucose values were demonstrated for all groups of handled reindeer.

\section{Body temperature}

There was a significant variation in body temperature between the groups. The highest temperature, $40.8^{\circ} \mathrm{C}$, was measured in a $1 \frac{1}{2}$ year old male from Test group 4.

\section{Meat investigations}

The pH 18-24 h post mortem was significantly higher in transported compared to free-ranging reindeer. One $2 \frac{1}{2}$ year old male from Test group 1 showed $\mathrm{pH}$ of 7.8 and the meat was dark, firm and dry. A high degree of correlation was established between plasma and meat urea, $\mathrm{r}=+0.8$.

Ammonia-like taint was observed in all groups except in Control group 1, and the two test persons agreed about $89 \%$ of the specimens. Four adult male reindeer showed strong ammonialike taint, while 5 male adult and 7 calves showed weak and barely detectable ammonia-like taint. There was no correlation between meat urea values and strength of meat ammonia-like taint. Taint that was referred to as gut content like by one test person was classified as other abnormal taint by the other. Therefore these two classes were combined and called other abnormal taints in Table 3. Other abnormal taints were observed in 5 male and 6 female adults and in 6 calves. The degree of taint was either weak of barely detectable. There was no correlation between ammonia-like taint and other abnormal taints. Neither were there any correlations between meat taints and levels of hormones and enzyme activities in plasma. Urea was not demonstrated in any rumen content specimen, but a significant variation between the groups in ammonia content and dry matter was found.

The rumen contents from the controls were coarse-grained and had a sour smell, while the rumen contents of reindeer from the test groups were fine-grained, watery and had a fecal smell. The correlation coefficient between plasma urea and rumen ammonia values was $+\mathbf{0 . 6 5}$. 


\section{DISCUSSION}

The prevalence of trauma was low except in Test group 2. It is likely that overloading and mixing of calves and adults were the reasons in this particular transport.

The plasma hormone measurements showed great individual variations. Elevated adrenaline and noradrenaline values in one of the free-ranging deer indicated that is was frightened by the hunter before is was shot. The catecholamine measurements also indicate that reindeer cope with being in the corral, while being locked up and transported on a lorry plane is a strong psychological strain on them. The cortisol values confirm this conclusion. The noradrenaline and adrenaline values obtained from transported reindeer are, as far as we know, the highest ever measured, without regards to species. Nevertheless, these reindeer controlled their body temperatures quite well.

Rehbinder et al. (1982) found myocardial and muscular degeneration in herded and handled reindeer, and capture myopathia is reported by Dietrich (1981).

In the present study transported reindeer showed only minor increase in plasma ASAT activity, while CK activity was strongly elevated. CK activity is currently accepted as the most specific marker of muscle damage for clinical use (Kaneko 1980). Nevertheless, in the horse a ten-fold increase in plasma CK activity has been demonstrated during a ride (Snow et al. 1982), and in pigs the CK activity is ofien used as an indicator of stress and muscle activity (Bickardt \& Richter 1980). The fact that CK activity decreased significantly when the reindeer were kept 6 $12 \mathrm{~h}$ after transport before slaughter, and ASAT activity was consistantly low, indicate that the muscular degeneration was not prominent.

Transproted reindeer showed elevated plasma glucose and urea values. This was most likely started by the psychological stress, releasing catecholamines and cortisol that eventually speeded up the glycogenolysis and protein catobolism. Hypoglycemia was never demonstrated, and the $\mathrm{pH} 18-24 \mathrm{~h}$ post mortem indicate that the muscle glycogen stores were not depleted.

Urea recycling in reindeer is a mechanism of adaption to low portein diet (Wales et al.1972), and theoretically elevated plasma urea values might be generated both from increased protein catabolism and impared rumen microbial protein synthesis. The fact 
that access to water is limited during gaihering and transport, that the kidneys are poorly circulated during catecholamine action and that reindeer have poor ability to concentrate urine (Hove \& Jacobsen 1975) all act to retain urea in the body. The present study demonstraies positive correlations between plasma urea, meat urea and rumen ammonia, but not correlation between meat urea and meat ammonia-like taint. The physiological mechanisms leading to the taints commonly observed in meat from handled and tiansported reindeer, are thus still unknown.

\section{ACKNOWLEDGEMENTS}

The project was financially supported by The Norwegian Development Foundation for Reindeer Management.

We thank Drs. Lars Beseth and Ole Haug for performance of the sensory analyses.

\section{REFERENCES}

Andersen, G.: Transportskader på rein ved ulike transportmidler. (Trauma on reindeer transported on differently fitted up lorries). Norsk Vet. Tidsskr. 1978, 90, 543-553.

Bichard, K. \& L. Richter: Metodische Aspekte des Creatin-Kinase-Tests (CK-Test) beim Schwein. (Method aspects of the CK-test in pigs). Dtsch. tierärztl. Wschr. 1980, 87, 296-298.

Chaney, A. L. \& E. P. Marback: Modified reagents for determination of urea and ammonia. Clin. Chem. 1962, 8, 130.

Da Prada, M. \& G. Zürcher: Simultaneous radioenzymatic determination of plasma and tissue adrenaline, nor-adrenaline and dopamin within the femtomol range. Life Sci. 1976, 19, 1161-1174.

Dietriech, R. A.: Capture myopathy. In Dietriech, R. A. (ed.) Alaskan Wildlife Diseases, University of Alaska, Fairbanks, Alaska 1981.

Hove, K. \& E. Jacobsen: Renal excretion of urea in reindeer. Effect of nutrition. Acta vet. scand. 1975, 16, 513-519.

Hyvärinen, H., T. Helle, M. Nieminen, P. Väyrynen \& R. Väyrynen: Some effects of handling reindeer during gatherings on the composition of their blood. Anim. Prod. 1976, 22, 105-114.

Kaneko, J. J.: Clinical Biochemistry of Domestic Animals. 3. ed. Academic Press, New York, London, Toronto 1980.

Marsh, W. H., B. Fingerhut \& H. Miller: Automated and manual direct methods for the determination of blood urea. Clin. Chem. 1965, $11,624-627$.

Rehbinder, C. \& L.-E. Edqvist: Influence of stress on some blood constituents in reindeer (Rangifer tarandus L.). Acta vet. scand. $1981,22,480 \_492$. 
Rehbinder, E., L.-E. Edqvist, K. Lundstrøm \& F. Villafane: A field study of management stress in reindeer (Rangifer tarandus L.) Rangifer 1982, 2, 2-21.

Snow, D. H., M. G. Kerr, M. A. Nimmo \& E. M. Abbot: Alterations in blood, sweat, urine and muscle composition during prolonged exercise in the horse. Vet. Rec. 1982, 110, 377-384.

Wales, R. A., L. P. Milligan \& E. H. McEwan: Urea recycling in caribou, cattle and sheep. Proc. 1st Symp. Reindeer and Caribou Res. Fairbanks, Alaska. 1972. In Luick, I. R., D. R. Klein, P. C. Lent \& R. G. White (eds.) : Biological papers Univ. Alaska. Spec. ser. No. 1, 1975.

\section{SAMMENDRAG}

Fysiologiske reaksjoner og effekter på kjøttkvalitet hos reinsdyr transportert på dyretransportbiler.

Reinsdyr som ble transportert til slakteri med dyretransportbiler viste sterkt forh $\varnothing y d e$ noradrenalin-, adrenalin- og cortisolverdier i plasma. Målinger av kreatin kinase og aspartat aminotransferase aktivitet $\mathrm{i}$ plasma indikerte at dyrene ikke hadde utviklet myopathier under transporten. Ved kokepr $\varnothing v e$ av kjøttet ble det fra $25 \%$ av de transporterte dyrene påvist ammoniakalsk og annen abnorm lukt. Kokeprøve av kjøtt fra reinsdyr som ble slaktet etter å ha oppholdt seg i samlekve i 36 timer viste like $h \varnothing y$ frekvens av disse luktene. Både ureainnholdet $\mathrm{i}$ plasma og kjøtt var forh $\varnothing$ yet $\mathrm{i}$ transporterte reinsdyr. Det var imidlertid ingen korrelasjon mellom ureainnholdet i kjøttet og intensiteten av ammoniakalsk lukt av kjøttet ved kokeprøve. Karakteren av den andre abnorme lukten som ble påvist ved kokeprøve kunne ikke defineres.

(Received November 25, 1983).

Reprints may be requested from: Ingolf Hanssen, Steinåsen 33, N-7000 Trondheim Norway. 